\title{
Postpartum Hamman's syndrome presenting with facial asymmetry
}

\author{
Julian Wijesuriya, Ruth Van Hoogstraten
}

Department of Anaesthetics and Intensive Care Medicine, Lister Hospital, Stevenage, UK

\section{Correspondence to} Dr Julian Wijesuriya, j.wij@nhs.net

Accepted 13 December 2015

\section{DESCRIPTION}

A 24-year-old primiparturient with suspected acute stroke was transferred urgently to the consultantled obstetric unit following normal vaginal delivery of a healthy baby under midwifery led care. The patient had no significant medical history and, other than having a low body mass index at booking $\left(17 \mathrm{~kg} / \mathrm{m}^{2}\right)$ and delivering a large baby (>90th centile), she had undergone a normal pregnancy and delivery.

Immediately following delivery, the patient developed facial asymmetry with left-sided swelling and drooping, and altered voice. Urgent clinical assessment revealed cardiorespiratory stability and, other than mild dysphonia, no evidence of acute stroke; there was marked surgical emphysema extending from the chest up to the face.

A portable chest radiograph demonstrated surgical emphysema but no evidence of pneumothorax. Ruptured oesophagus was suspected and a CT of the neck and chest with contrast was requested. This demonstrated pneumomediastinum, a small apical pneumothorax and no evidence of oesophageal rupture (figure 1).

The diagnosis of Hamman's syndrome was made and, following a period of observation and conservative management, the patient was discharged home with outpatient respiratory follow-up.

Hamman's syndrome describes the rare complication of straining affecting 1:100 000 live births in

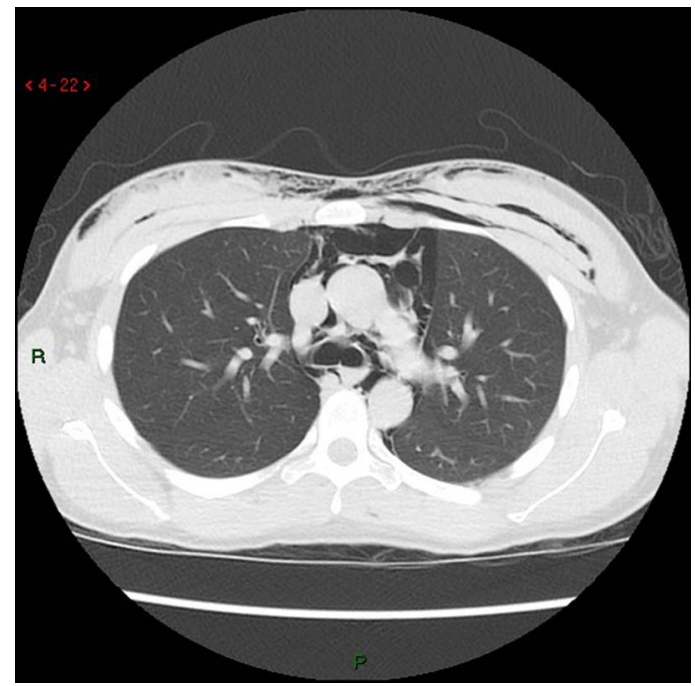

Figure $1 \mathrm{CT}$ of the chest (axial slice at T5) demonstrating a small left apical pneumothorax, pneumomediastinum and extensive surgical emphysema affecting the anterior chest wall.

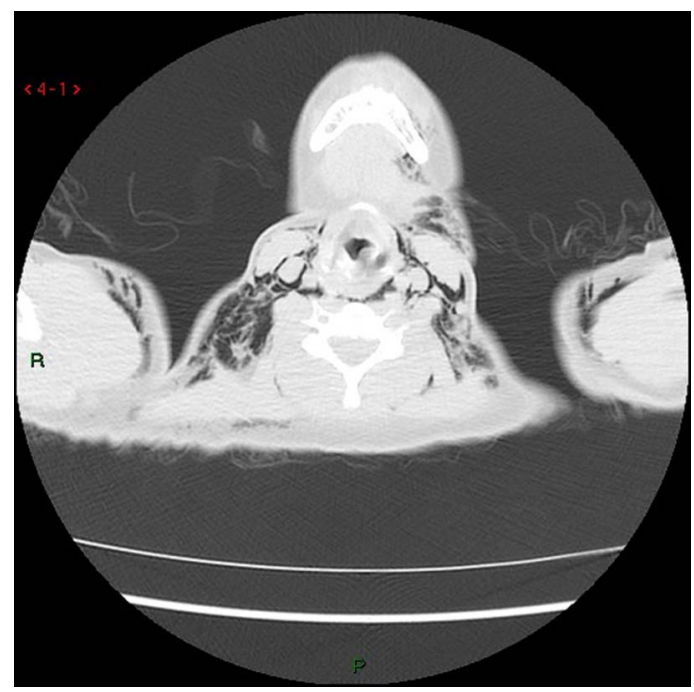

Figure 2 CT of the neck (axial slice at C6) demonstrating surgical emphysema in the neck extending towards the left side of the mandible and causing subtle left-sided compression of the larynx.

which barotrauma results in lung injury, pneumomediastinum and surgical emphysema. ${ }^{1}$

Treatment is usually conservative, however, it is important to fully investigate such patients to exclude other diagnoses such as Boerhaave's syndrome, which may require surgical intervention. ${ }^{2}$ Extensive surgical emphysema may distort head and neck anatomy, with resultant facial and vocal changes suggesting neurological pathology (figure 2). However, thorough clinical examination should narrow the differentials and radiological investigation will confirm the diagnosis.

\section{Learning points}

- Hamman's syndrome is a rare complication of normal labour.

- The diagnosis must be urgently differentiated from the more serious Boerhaave's syndrome.

- Extensive surgical emphysema may cause facial asymmetry and dysphonia, mimicking stroke.

Contributors JW and RVH made substantial contributions to the conception or design of the manuscript. JW drafted the manuscript and $\mathrm{RVH}$ revised it critically for important intellectual content. Both the authors gave final approval of the version to be published and agree to be accountable for all aspects of the work in ensuring that 
questions related to the accuracy or integrity of any part of the work are appropriately investigated and resolved.

Competing interests None declared.

Patient consent Obtained.

Provenance and peer review Not commissioned; externally peer reviewed.

\section{REFERENCES}

1 Majer S, Graber P. Postpartum pneumomediastinum (Hamman's syndrome). J Obstet Gynaecol Can 2006;28:128-31.

2 Beynon F, Mearns S. Spontaneous pneumomediastinum following normal labour. BMJ Case Rep 2011;2011.

Copyright 2015 BMJ Publishing Group. All rights reserved. For permission to reuse any of this content visit

http://group.bmj.com/group/rights-licensing/permissions.

BMJ Case Report Fellows may re-use this article for personal use and teaching without any further permission.

Become a Fellow of BMJ Case Reports today and you can:

- Submit as many cases as you like

- Enjoy fast sympathetic peer review and rapid publication of accepted articles

- Access all the published articles

- Re-use any of the published material for personal use and teaching without further permission

For information on Institutional Fellowships contact consortiasales@bmjgroup.com

Visit casereports.bmj.com for more articles like this and to become a Fellow 